\title{
Isolation and Molecular Characterization of Brucella melitensis from Abortion Storms in Sheep with its Zoonotic Implications
}

\author{
D.K. Sharma ${ }^{1}$, B. Bhardwaj ${ }^{2}$, H.C. Chouhan ${ }^{3}$, B.S.Chandel, \\ B. Joseph ${ }^{1}$ and S.K. Barolia ${ }^{4 *}$ \\ ${ }^{1}$ Department of Microbiology, College of Veterinary and Animal Sciences, Navania, \\ Vallabhanagar, Udaipur, Rajasthan - 313601, India \\ ${ }^{2}$ Regional Disease Diagnostic Center, Department of Animal Husbandry Udaipur, \\ Rajasthan, India \\ ${ }^{3}$ Department of Microbiology \& Animal Biotechnology, College of Veterinary Science and \\ Animal Husbandry, Sardarkrushinagar, Dantiwada, Gujarat-385506, India \\ ${ }^{4}$ Department of Zoology, University College of Science, ML Sukhadia University, Udaipur, \\ Rajasthan-313001, India \\ *Corresponding author
}

\section{A B S T R A C T}

Outbreak of brucellosis has been recorded in sheep flocks in Udaipur district of Rajasthan, India. Total 15 abortions were recorded in two flocks of 115 sheep. Samples from aborted

\section{Keywords}

Brucellosis, Real time PCR, Brucella melitensis, Sheep, Udaipur, Rajasthan

\section{Article Info}

Accepted: 12 September 2018 Available Online: 10 October 2018 fetus, retained placenta colostrum and sera samples were collected. Sera samples were tested by Rose Bengal plate agglutination test. Culture and isolation were done on selective media. All tested sera samples were found positive for brucellosis while Brucella melitensis was isolated from fetal abomasal content and placenta samples. Three isolated strains were subjected to molecular characterization by Real time PCR using BCSP31 gene specific oligonucliotide primer pair in real time PCR with SYBR Green chemistry. Further these isolates were confirmed by Taqman probe chemistry with IS711 gene. Species level characterization was done by Bruce ladder PCR. Outbreak of Brucellosis has been confirmed. Three strains were isolated and by molecular characterization found to be Brucella melitensis. All sheep examined found serologically positive for brucellosis. This is a primary report of culture confirmation of Brucella melitensis outbreak in southern Rajasthan. Study show the occurrence of Brucella melitensis in the area which is of major zoonotic concern. Here we are reporting first time isolation and molecular confirmation of Brucella melitensis in sheep from Udaipur district of Rajasthan

\section{Introduction}

Brucellosis has worldwide distribution and is more common in countries with poor animal and public health programme. Brucella melitensis is most virulent species of Brucella genus and has zoonotic potential (Aparcio, 2013). Goats are classical natural host of $B$. melitensis together with sheep as its preferred host with main clinical signs of abortion, retention of placenta, still birth and infertility (Blasco and Molina-Flores, 2011).

Brucellosis remains an important contagious 
disease with zoonotic significance. It affects approximately 500,000 people annually globally (Aparcio, 2013). It is endemic in many parts of world including India, in developing country like India this disease remains highly neglected but it is endemic and important zoonoses (Aparcio, 2013; Blasco and Molina-Flores, 2011 and Kumar, 2010). The disease is responsible for heavy economic losses due to abortions, still birth and infertility. Economic losses due to Brucellosis in India have been estimated USD 3.4 Million annually (Singh et al., 2015). Brucellosis in sheep and goat is primarily caused by Brucella melitensis, while in cattle the primary causative agent is B. abortus (Aparcio, 2013). The most reliable and gold standard methods for diagnosis and confirmation of the disease is bacterial isolation and identification (Chand et al., 2012). Further its molecular characterization by PCR from culture leads to confirmation and species level characterization of the causative agents (Chand et al., 2012).

Present paper report storm of abortions caused by Brucella melitensis its culture and molecular confirmation in sheep flocks from a village of Udaipur district of Rajasthan. The results contribute to better understanding of epidemiological distribution of Brucella melitensis and are important in development of prevention and control strategies. In hilly tract of Arawali region farmers have close association with sheep and goats, with it these sheep and goat share pasture land of village with other livestock. So the infected sheep may act as a potential source of infection to human beings as well as other livestock.

To the best of our knowledge, present paper is a primary report of culture, isolation and molecular characterization of Brucella melitensis from storms of abortion in sheep flocks from Southern Rajasthan.

\section{Materials and Methods}

Ethical approval: Sample collection and disease diagnosis is part of routine work of regional disease diagnostic centre Department of animal Husbandry Udaipur, hence no ethical approval required

\section{Description of village, animal husbandry and the sheep flock}

Village Mading Pura of Bhinder tehsil involved in this study is located about $60 \mathrm{KM}$ away from Udaipur city of Rajasthan state. The flocks under consideration were owned by two persons, Mr. Mangu Lal and Mr. Sambhu Lal Gadri of Mading Pura village. These two flocks consist of 55 and 60 sheep of Sonadi breed respectively out of which 26 male and rest were female.

The total number of sheep in the village is 160. These sheep are maintained by open grazing method with one time a day concentrate (barley) feeding. These sheep share pasture with cattle and buffalo of the village. The poor country men keep small flock up to 60 sheep, for their bread and butter, animals are sold for meat purpose and wool is sheared two times in a year. In this way these sheep are moving bank for the farmers.

\section{History of abortions}

First abortion was observed in the month of August 2015 followed by a storm of abortions and 15 abortions were recorded by owners. All these abortions were followed by retention of placenta and metritis. In this way, the abortions continued and owner reported at regional disease diagnostic center, (RDDC) department of animal husbandry (DAH), Udaipur, Rajasthan. A team of Assistant professors from department of veterinary microbiology, veterinary pathology, College 
of veterinary and animal science Navania, Udaipur and Veterinary officers from RDDC visited the village and samples were collected.

\section{Collection and handling of blood samples}

Approximately $7 \mathrm{ml}$ venous blood sample was collected from sheep having history of abortion and from all adult male sheep in flock (total 26). The blood samples were allowed to clot for 15-20 minutes and were bought at department of Veterinary Microbiology, C.V.A.S Navania, on ice for serological testing. Serum was separated by centrifugation at 3000 RPM for 10 minutes. Sera samples were stored at - 20 degree centigrade till further use.

\section{Collection and handling of vaginal swab and fetal abomasal content}

Vaginal swabs were collected from recently aborted sheep. Fetal abomasal content and heart blood were collected by postmortem of available fetus. And milk samples collected from all sheep aborted in recent past (in Aug and Sept 2015). Detail of sample shown in table 1 .

\section{Serological test}

For serological testing Rose Bengal Plate Agglutination Test (RBPT), was performed as per protocol supplied by manufacturer (IVRI BP Lab UP, INDIA).

\section{Bacterial culture}

All samples were sent to Department of Animal Biotechnology and Microbiology laboratory, College of Veterinary Sciences and Animal Husbandry (A center of Network project on Brucellosis), Dantiwada Gujarat for culture and isolation. Samples were streaked on Brucella selective agar (Himedia cat. No. M 0074), supplemented with horse serum
(Himedia cat. No. RM 1239-100ml) antibiotic and anti-fungal (Ready mix of Himedia cat. No. FD 005) Containing per ml Bacitracin $25 \mu \mathrm{g}$, polymixin $5 \mathrm{IU}$; Cyclohexamide100u $\mathrm{ug}$ and Nalidixic acid $5 \mu \mathrm{g}$ and nystatin $100 \mu \mathrm{g}$. and inoculated into Brucella selective broth tubes

The inoculated plate and broth tubes were incubated in Maclintose anaerobic cultivation Jar with candle light in it to improve $\mathrm{CO}_{2}$ concentration and one set incubated aerobically. After five days incubation, broth tubes had fungal contamination and hence discarded after autoclaving. Petri plate had smooth bluish colonies with translucent moist and 2-4 $\mathrm{mm}$ in diameter were considered suspected colonies.

Primary characterization was carried out by catalase test, oxidase test and modified $\mathrm{ZN}$ staining as described (Quinn et al., 2000). Positive colonies were transferred to glycerol BHI broth and stored at -20 degree centigrade till further use. These suspected cultures were used for molecular characterization by PCR methods.

\section{Molecular characterization}

DNA extraction - DNA extraction was carried out using DNAeasy blood and tissue kit (Qiagen cat. no. 69540 and 69506) as per the standard protocol provided by the manufacturer, described here briefly - One $\mathrm{ml}$ of Broth culture was centrifuged at $300 \mathrm{~g}$ and re-suspended in $200 \mu \mathrm{l} \mathrm{PBS}$ and protinase $\mathrm{K}$ $20 \mu \mathrm{l}$ was added. To it $200 \mu \mathrm{l}$ buffer Al mix was added and mixed thoroughly by vortexing and $200 \mu \mathrm{l}$ ethanol $(96 \% \mathrm{~V} / \mathrm{V})$ was added and was mixed thoroughly by vortexing. Mixture was transferred to DNase mini spin column and placed in a $2 \mathrm{ml}$ collection tube it was centrifuged at $6000 \mathrm{~g}$ for $1 \mathrm{~min}$ and flow was discarded. The spin column was placed in a

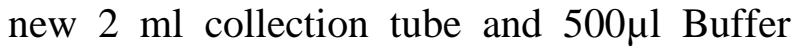


(AW1) was added to it and centrifuged at $6000 \mathrm{~g}$ for $1 \mathrm{~min}$ and flow was discarded. The spin column was placed in a new $2 \mathrm{ml}$ collection tube and $500 \mu \mathrm{l}$ Buffer (AW2) was added and centrifuged for 3 minutes at 20,000 g. The spin column was Transferred to new 2 $\mathrm{ml}$ micro centrifuge tube and DNA was eluted by adding $200 \mu \mathrm{l}$ buffer (AE) to the center of the spin column membrane. It was incubated for one minute at room temperature and centrifuged at $6000 \mathrm{~g}$.

Molecular characterization and identification of Brucella genus was first done using BCSP31 gene specific oligonucliotide primer pair in real time PCR with SYBR Green chemistry (Baily et al., 1992). The reaction mixture as well as PCR cycle conditions follows as per Table 2. This reaction showed melting value $(\mathrm{Tm}) 87^{\circ} \mathrm{C}$ directly matches with positive control. Then again Brucella genus level molecular characterization was carried out by real time PCR for conformation on extracted genomic DNA with Taqman probe chemistry with IS711 gene (Newby et $a l ., 2003)$ and this reaction mixture as well as PCR cycle conditions according to Table 3 .

Amplification and fluorescence detection were done in real time PCR (Applied Biosystem 7500 Real time PCR system) with samples, positive and negative control included. When the cycle threshold (CT) values were evaluated as positive $18.75,19.10$ and 20 as per DNA concentration of samples in this real time PCR was designed for detection of genus level characterization as it has genus specific probe only.

Brucella species confirmation has been carried out on all three isolates found positive in real time PCR analysis using Bruce ladder multiplex PCR assay, selected primer as per described (Gracia-yoldi et al., 2006) and PCR reaction mixture as well as thermal cycle conditions were provided as per Table 4, after than run PCR product in $2 \%$ gel electrophoresis for observation of amplified product.

\section{Results and Discussion}

Outbreak of Brucellosis has been confirmed by serological tests, culture and isolation. Three strains of Brucella melitensis were isolated and confirmed by PCR methods. Study show the occurrence of Brucella melitensis in the area which is of major zoonotic concern.

\section{Bacterial isolation}

A total three isolates were obtained from Twenty eight samples collected and confirmed as Brucella melitensis. Two isolate were obtained from vaginal swabs while one isolate was from fetal abomasal content. Isolates could not be recovered from milk/colostrum.

\section{Identification of Brucella melitensis isolates}

All Brucella strains were identified as Brucella melitensis by biochemical characteristics i.e. Modified $\mathrm{ZN}$ positive, No $\mathrm{CO}_{2}$ requirements for growth and oxidase positive. Twenty six out of 115 sheep were found positive in RBPT. Three isolate of Brucella melitensis were obtained from sample collected. All isolates have typical colonial appearance viz. translucent bluish smooth colonies. With modified $\mathrm{ZN}$ positive staining and Catalase and Oxidase test positive.

\section{Real time PCR and Bruce ladder PCR for confirmation}

Further Genus level identification was carried out by Real time PCR and species level identification carried out by Bruce ladder multiplex PCR as described and confirmed as Brucella melitensis further for biotyping the 
culture were sent to Indian Veterinary Research Institute U.P. India.

Storm of abortions due to brucellosis leads to rapid spread of pathogen among animals and humans so it needs immediate attention. Storm of abortions in cattle as well as sheep and goat have been reported by many workers from all over the world (Blasco and Molina-Flores, 2011; Chand et al., 2012; Chahota et al., 2003; Sharma et al., 2008 and Al-Garadi et al., 2011). Many studies of sero-prevalence indicate the occurrence of brucellosis in India and abroad (Chahota et al., 2003; Kumar et al., 1997; Lone et al., 2013; Suryawanshi et al., 2014; Mantur and Amarnath, 2008; Mugizi et al., 2015). Sero-prevalence reports from Rajasthan indicate the presence of the disease (Leyla et al., 2003). But there is not a single report of culture confirmation of $B$. melitensis from Southern Rajasthan.

In our study we observed 15 abortions in two flocks of 115 sheep. We could obtain Three Brucella melitensis isolates, two from vaginal swabs and one from fetal abomasal contents. Isolation of Brucella melitensis form vaginal swab is in accordance of above researchers from India (Chand et al., 2012; Sharma et al., 2008) and abroad (Sharma et al., 2008; AlGaradi et al., 2011). It was also observed that vaginal swab samples were relatively easy to obtain and process for bacterial isolation in laboratory. whereas Brucella melitensis culture from Fetal abomasal content was not reported by above cited researchers (except Chand P. et al., who reported two isolate in 2004 and one isolate in 2006 and 23) fetal abomasal content is most reliable source for pure culture of etiological agent from abortion cases (Sonawane et al., 2011). So obtaining pure culture from fetal abomasal content is significant. Though excretion of Brucella from milk is well documented and reported (Chand et al., 2012). But we could not recover any isolate from milk/colostrum. This might be due to variation in culture media we used and/or centrifugation procedure described elsewhere was not used by us (Chand et al., 2012). Orchitis and epididymitis have been reported in affected Ram (Chand et al., 2012). But in our study we examined more than 20 Rams and could not find Orchitits/ epididymitis in any Ram of affected flock.

Table.1 Animals and samples detail

\begin{tabular}{|l|l|l|l|l|l|}
\hline Sex & Group & $\begin{array}{l}\text { Number of } \\
\text { animal } \\
\text { examined }\end{array}$ & $\begin{array}{l}\text { Number of } \\
\text { animal } \\
\text { positive by } \\
\text { serological } \\
\text { test }\end{array}$ & \multicolumn{2}{|c}{ Culture } \\
\hline & & & RBPT & $\begin{array}{l}\text { Sample } \\
\text { collected }\end{array}$ & Positive \\
\hline Male & Adult & 14 & 1 & Nil & Nil \\
\hline & Sub-adult & 12 & Negative & Nil & Nil \\
\hline & Lamb & 12 & Negative & Nil & Nil \\
\hline Female & Adult & 43 & 25 & 14 & 3 \\
\hline & Sub-adult & 34 & Negative & Nil & Nil \\
\hline & Lamb & - & Negative & Nil & Nil \\
\hline Total & & 115 & 26 & 14 & 3 \\
\hline
\end{tabular}


Table.2 PCR reaction mixtures and cycle condition for SYBR Green chemistry with B4/B5 primer pair

\begin{tabular}{|c|c|c|c|c|c|c|c|}
\hline \multicolumn{8}{|c|}{ Genus specific primers : } \\
\hline Sr. No & \multicolumn{2}{|c|}{ Primer } & $\begin{array}{l}\text { Forward/ } \\
\text { Reverse }\end{array}$ & \multicolumn{2}{|c|}{ Sequence (5'-3') } & $\begin{array}{l}\text { Product size } \\
\text { (bp) }\end{array}$ & Reference \\
\hline 1. & \multicolumn{2}{|c|}{ B4 (BCSP31) } & Forward & \multicolumn{2}{|c|}{ TGG CTC GGT TGC CAA TAT CAA } & \multirow[t]{2}{*}{223 bp } & \multirow[t]{2}{*}{ (7) } \\
\hline 2. & \multicolumn{2}{|c|}{ B5 (BCSP31) } & Reverse & \multicolumn{2}{|c|}{ CGC GCT TGC CTT TCA GGT CTG } & & \\
\hline \multicolumn{8}{|c|}{ PCR reaction mixture } \\
\hline \multicolumn{2}{|c|}{ Sr. No } & \multicolumn{3}{|c|}{ Components } & \multicolumn{2}{|c|}{ Aliquot $(\mu \mathrm{I})$} & \\
\hline \multicolumn{2}{|c|}{1.} & \multicolumn{3}{|c|}{ PCR Master Mix (2X) } & \multicolumn{2}{|c|}{$12.5 \mu \mathrm{l}$} & \\
\hline \multicolumn{2}{|c|}{2.} & \multicolumn{3}{|c|}{ Forward Primer (10 pmol/ul) } & \multicolumn{2}{|r|}{$1 \mu \mathrm{l}$} & \\
\hline \multicolumn{2}{|c|}{3.} & \multicolumn{3}{|c|}{ Reverse Primer (10 pmol/ul) } & \multicolumn{2}{|r|}{$1 \mu \mathrm{l}$} & \\
\hline \multicolumn{2}{|c|}{4.} & \multicolumn{3}{|c|}{ Template DNA } & \multicolumn{2}{|r|}{$2 \mu 1$} & \\
\hline \multirow{2}{*}{\multicolumn{2}{|c|}{5.}} & \multicolumn{3}{|c|}{ Nuclease free water } & \multicolumn{2}{|r|}{$8.5 \mu \mathrm{l}$} & \\
\hline \multicolumn{7}{|c|}{ Conditions of thermal cycling primer pair B4/B5 } & \\
\hline \multicolumn{3}{|l|}{ Steps } & \multicolumn{2}{|c|}{ Temperature } & \multicolumn{2}{|c|}{ Duration } & of cycle \\
\hline \multicolumn{3}{|c|}{ Initial Denaturation } & \multicolumn{2}{|c|}{$93^{\circ} \mathrm{C}$} & $5 \mathrm{~min}$. & & ycles \\
\hline Denatu & tition & & & $95^{\circ} \mathrm{C}$ & 30min. & & cycles \\
\hline Anneal & & & & $55^{\circ} \mathrm{C}$ & $30 \mathrm{sec}$. & & \\
\hline Extensi & & & & $72^{\circ} \mathrm{C}$ & $30 \mathrm{~min}$. & & \\
\hline Melt cu & vec & & & $95^{\circ} \mathrm{C}$ & $15 \mathrm{sec}$ & & $1 \mathrm{hr}$ \\
\hline & & & & $60^{\circ} \mathrm{C}$ & $15 \mathrm{sec}$ & & \\
\hline
\end{tabular}

Table.3 TaqMan probe based Real Time PCR for Molecular characterization of Brucella

\begin{tabular}{|c|c|c|c|c|}
\hline \multicolumn{5}{|c|}{ TaqMan probe based Real Time PCR (8) } \\
\hline Sr. No. & Components & & \multicolumn{2}{|l|}{ Aliquot $(\mu \mathrm{l})$} \\
\hline 1. & \multicolumn{2}{|c|}{$\begin{array}{l}\text { Universal PCR Master Mix without } \\
\text { UNG }(2 X)\end{array}$} & \multicolumn{2}{|c|}{$12 \mu \mathrm{l}$} \\
\hline 2 & \multirow{2}{*}{\multicolumn{2}{|c|}{$\begin{array}{l}\text { Forward Primer }(10 \mathrm{pmol} / \mu \mathrm{l}) \\
\text { Reverse Primer }(10 \mathrm{pmol} / \mu \mathrm{l})\end{array}$}} & \multicolumn{2}{|c|}{$1 \mu 1$} \\
\hline 3 & & & \multicolumn{2}{|c|}{$1 \mu 1$} \\
\hline 4. & \multicolumn{2}{|c|}{ Template DNA } & \multicolumn{2}{|c|}{$2 \mu 1$} \\
\hline 5. & \multicolumn{2}{|c|}{ Nuclease free water } & \multicolumn{2}{|c|}{$5 \mu 1$} \\
\hline 6 & \multicolumn{2}{|c|}{ 50X IPC DNA } & \multicolumn{2}{|c|}{$0.5 \mu 1$} \\
\hline 7 & \multicolumn{2}{|c|}{ 10X IPC mixture } & \multicolumn{2}{|c|}{$2.5 \mu 1$} \\
\hline 8 & \multicolumn{2}{|c|}{ Probe $(20 \mathrm{pmol} / \mu \mathrm{l})$} & \multicolumn{2}{|c|}{$1 \mu \mathrm{l}$} \\
\hline \multicolumn{5}{|c|}{ Thermal cycle condition for probe based assay } \\
\hline & Steps & Temperature & Duration & Number of cycle \\
\hline & Pre holding stage & $95^{\circ} \mathrm{C}$ & $10 \mathrm{~min}$. & 1 cycles \\
\hline \multirow{2}{*}{\multicolumn{2}{|c|}{ Cycling stage }} & $95^{\circ} \mathrm{C}$ & $30 \mathrm{sec}$ & \multirow[t]{2}{*}{40 cycles } \\
\hline & & $60^{\circ} \mathrm{C}$ & $50 \mathrm{sec}$ & \\
\hline & Post PCR read & $60^{\circ} \mathrm{C}$ & $1 \mathrm{~min}$. & 1 cycles \\
\hline
\end{tabular}


Table.4 PCR reaction mixture and thermal cycle condition for Bruce ladder multiplex PCR

\begin{tabular}{|c|l|c|c|}
\hline \multicolumn{5}{|c|}{ Bruce ladder (multiplex PCR) for species identification } \\
\hline Sr. No. & Components & Aliquot $(\boldsymbol{\mu l})$ \\
\hline 1. & PCR Master Mix $(2 \mathrm{X})$ & $15 \mu \mathrm{l}$ \\
\hline 2. & Primer Mix $(6.25 \mathrm{Pmol} / \mu \mathrm{l})$ & $2 \mu \mathrm{l}$ \\
\hline 3 & Template DNA & $2 \mu \mathrm{l}$ \\
\hline 4 & Nuclease free water & $10 \mu \mathrm{l}$ \\
\hline 5 & $10 \mathrm{mg} / \mathrm{ml} \mathrm{MgCl} 2$ & $1 \mu \mathrm{l}$ \\
\hline \multicolumn{4}{|c|}{ Bruce ladder thermal cycle condition } \\
\hline Steps & Temperature & Duration & Number of cycle \\
\hline Initial Denaturation & $95^{\circ} \mathrm{C}$ & 5 min. & 1 cycles \\
\hline Denaturation & $90^{\circ} \mathrm{C}$ & 1 min. & 35 cycles \\
\hline Annealing & $60^{\circ} \mathrm{C}$ & $1 \mathrm{~min}$ & \\
\hline Extension & $72^{\circ} \mathrm{C}$ & 2 min. \\
\hline Final extension & $72^{\circ} \mathrm{C}$ & 10 min. & 1 cycles \\
\hline
\end{tabular}

Adopting a new methodology after primary characterization by preliminary tests viz Modified ZN, Oxidase positive colonies were isolated and subjected to rear time PCR. All three isolates were confirmed using BCSP31 gene specific oligonucliotide primer pair in real time PCR with SYBR Green chemistry (Baily et al., 1992). To clear the doubt in results it was further confirmed using Taqman probe chemistry with IS711 gene (Newby et al., 2003). This method not only reduces the handling of most zoonotic strain of Brucella in laboratory but also reduce the chance of aerosol formation in the environment. Confirmation of Brucella melitensis species was carried out by Bruce ladder PCR as described.

All examined sera samples were found positive in Rose Bangle Plate agglutination Test seroprevalence study conducted by many researchers from India (Chahota et al., 2003; Kumar et al., 1997; Lone et al., 2013; Suryawanshi et al., 2014; Mantur and Amarnath, 2008; Mugizi et al., 2015) but culture confirmation is very scanty (Chand $e t$ al., 2012; Sharma et al., 2008).Culture confirmation and molecular characterization of Brucella spp. documented well abroad (AlGaradi et al., 2011, Sonawane et al., 2011). And a few report of seroprevelence brucellosis from Rajasthan (Leyla et al., 2003), however up to our best knowledge there is not a single report of culture, isolation and molecular confirmation of Brucella melitensis by real time PCR from Rajasthan. This is a major hurdle in determining the species and biovar prevalent in the area. Isolation and molecular characterization up to species level of the pathogen plays a major role in determining the prevention and control strategy. Successful isolation and species level molecular characterization of Brucella melitensis is therefore very significant. Zoonotic importance of Brucella melitensis is well documented (Renukaradhya et al., 2002; Smits and Manzoor, 2005). In our study both the owners of the flock were having history of orchitis and infertility. It also indicates the zoonotic potential of the organism isolated from the flock. The situation needs immediate prevention and control intervention. The reports of investigation were handed over to Department of Animal Husbandry, Udaipur Rajasthan for necessary preventive and therapeutic measures. 
Source of infection in the flock although could not be ascertain yet sero-prevalence report of brucellosis in semiarid Rajasthan (Sonawane et al., 2011) give a clue regarding spread of the disease. Sero-positive animal though not abort but spread the organism at the time of parturition (Renukaradhya et al., 2002) so previously infected animal may act as potential carrier throughout its life (Smits and Manzoor, 2005). This spread might be due to migratory sheep. Because these migratory flocks have tract of movement from desert of Thar (arid and semiarid Rajasthan) to Madhya Pradesh state and back annually. In between these sheep share common pasture of native sheep and they stay there for few days. So these migratory sheep may be a source of infection in the area. For further clarification, study about current status of brucellosis in migratory sheep flock needed.

Conclusion: Primary report of isolation and molecular characterization of Brucella melitensis from abortion storm among sheep flocks from Udaipur district of Rajasthan.

Twenty six out of 115 sheep were found positive in RBPT. Three isolate of Brucella melitensis were obtained from sample collected. All isolates have typical colonial appearance viz. translucent bluish smooth colonies.

With modified $\mathrm{ZN}$ positive staining and Catalase and Oxidase test positive. Genus level identification was carried out by Real time PCR and species level identification carried out by Bruce ladder multiplex PCR as described. And confirmed as Brucella melitensis further for biotyping the culture were sent to Indian Veterinary Research Institute U.P. India.

\section{Competing interests}

Authors have no competing interests.

\section{References}

Al-Garadi M. A. Bejo K.S. Zunita Z. and Omar R.A. 2011. Isolation and Identification of Brucella melitensis in goats J. Anim.Vet.Adv., 10(8): pp.872979

Aparcio E. D. 2013. Epidemiology of brucellosis in domestic animals caused by Brucella melitensis, Brucella suis and Brucella abortus Rev.sci.tech. int.Epiz., 32(1), pp.53-60

Baily GG, Krahn JB, Drasar BS, Stoker NG 1992. Detection of Brucella melitensis and Brucella abortus by DNA amplification 1992 Aug; 95(4): pp.2715.

Blasco J.M. and Molina-Flores B. 2011. Control and eradication of Brucella melitensis infection in sheep and goats Vet. Clin. N. Am. (Food Anim. Pract.), 27(1), pp.95-104

Chahota, R., Sharma M., Katoch R. C, Verma S., Singh M. M., Kapoor V., Asrani R. K. 2003. Brucellosis outbreak in an organized dairy farm involving cows and in contact human beings, in Himachal Pradesh, India. Vet. Arhiv., 73, pp. 95-102.

Chand P., Rajpurohit B. S. and Batobyal A., 2012. Control of brucellosis at an endemically infected sheep farm in Haryana India) Indian Journal of Animal Sciences 82 (4). pp. 343-347

Gracia-yoldi D., Martin C. M., De-Miguel M.J., Munoz P.M. Vizmanos J. L., and Lopez-Goni I. 2006. Multiplex PCR assay for the identification and differentiation of all Brucella species and the vaccine strains Brucella abortus S19 and RB51 and Brucella melitensis Rev1. Clin. Chem., 52(4) pp.779-781

Kumar A. 2010 Brucellosis: need of public health intervention in rural India Contributions, Sec. Biol. Med. Sci., MASA, XXXI, 1, pp. 219-231 
Kumar P., Singh D.K., and Brabuddhe S.B. 1997. Serological evidence of brucellosis in sheep and goats Indian Journal of Anim. Sc. 67: pp.180-182

Leyla, G. G. Kadri and O. Umran, 2003. Comparison of polymerase chain reaction and bacteriological culture for the diagnosis of sheep brucellosis using aborted fetus samples. Vet. Microbiol. 93:53-61

Lone M. I., Baba A.M., Shah M. M., Iqbal A. and Sakina A. 2013. Sero-prevalence of brucellosis in sheep of organized and unorganized sector of Kashmir valley doi:10.5455/vet.world.530-533

Mantur B.G., and Amarnath S.K. 2008. Brucellosis in India - a review. Journal of Biosciences: 33(4): 539-47

Mugizi D. R., Muradrasoli S., Boqvist S., Erume J., Nasinyama G. W., Waiswa C., Mboowa G., Klint M., and Magnusson L.F. 2015 Isolation and molecular characterization of Brucella isolates in cattle milk in Uganda. BioMed Research International (2015), http://dx.doi.org/10.1155/2015/720413

Newby D. T. Hadfield T. L and Roberto F. F. 2003. Real-Time PCR Detection of Brucella abortus: a Comparative Study of SYBR Green I, 5'Exonuclease, and Hybridization Probe Assays Appl Environ Microbiol. Aug; 69(8): $\quad 4753-4759 . \quad$ doi 10.1128/AEM.69.8. pp. 4753-4759.
Quinn P.J., Carter M.E., Markey B., and Carter G.E. 2000. Clinical veterinary microbiology MOSBY Publishing House, pp 261-267

Renukaradhya G.J., Isloor S. and Rajasekhar M. 2002. Epidemiology, zoonotic aspects, vaccination and control/eradication of brucellosis in India. Veterinary Microbiology; 90: 183-95

Sharma M., Batta M. K., Katoch, R. C., and Andersen A.A., 2008. Field investigation of bacterial etiology of abortions among migratory sheep and goats in North-West hill states of India Veterinarski Arhiv 78 (1): pp.65-71,

Singh, B.B., Dhand N.K., and Gill J.P.S., 2015. Economic losses occurring due to brucellosis in Indian livestock populations. PREVET, prevetmed. http://dx.doi.org/10.1016/j

Smits H.L., and Manzoor K. 2005. Brucellosis in India: A deceptive infectious disease. Indian Journal of Medical Research; 122:375-84. 9.

Sonawane G. G., Tripathi S. And Dubey C. S. 2011. Sero-incidence of brucellosis in small ruminants of semiarid Rajasthan Indian Journal of Animal Sciences 81 (4): $327-29$

Suryawanshi N.S., Tembhurne A. P., Gohain S., and Ingle C. V. 2014. Prevalence of Brucella antibodies in Sheep and Goats in Maharashtra. Indian Res. J. Ext. Edu. 14 (4). $75-77$

\section{How to cite this article:}

Sharma, D.K., B. Bhardwaj, H.C. Chouhan, B.S.Chandel, B. Joseph and Barolia, S.K. 2018. Isolation and Molecular Characterization of Brucella melitensis from Abortion Storms in Sheep with its Zoonotic Implications. Int.J.Curr.Microbiol.App.Sci. 7(10): 1348-1356. doi: https://doi.org/10.20546/ijcmas.2018.710.150 